\title{
Legal fight looms over patent bid on human/animal chimaeras
}

[LONDON] One of the biotechnology industry's fiercest critics has fired a shot across its bows by applying for a broad patent on methods for creating 'human/animal chimaeras', a description covering a wide range of experiments in which human cells are fused into an animal embryo, or vice versa.

The patent has been applied for jointly by Jeremy Rifkin, president of the pressure group Foundation on Economic Trends in Washington DC, and author of several books attacking the use of genetic engineering techniques, and Stewart Newman, professor of cell biology and anatomy at New York Medical College, and a long-standing member of the Council for Responsible Genetics.

Rifkin describes it as the "ultimate [patent] prize", given the many potential applications of introducing human cells into animal embryos. Research fields range from testing drugs for teratogenic effects to xenotransplantation.

So far, a combination of scientific difficulties and ethical reluctance has constrained researchers from experimenting with the creation of chimaeric embryos involving human cells. Indeed, in some countries — including Britain and Germany - this is illegal.

Rifkin and Newman have exploited the fact that, in the United States, where no such

law exists, a patent application need not be based on an actual experiment, but can be based merely on the description of a hypothetical experiment, provided the patent office can be persuaded of its credibility.

"There is no need to have actually carried out the experiment, providing the idea meets the standard criteria for patentability," says Pat Coyne, of the Washingtonbased attorneys Collier, Shannon, Rill and Scott, who have filed the patent. "We are certainly not aware of any 'prior art." Coyne also argues that a lack of evidence that others have made similar proposals means that the application meets the claim of 'non-obviousness'.

The two applicants say that if they are granted the patent, they will use it for 'genetic conservancy', to prevent the commercial exploitation of the techniques before there has been a full public discussion of their implications.

If the patent application is rejected by the US Patent and Trademark Office, Rifkin and Stewart say they will take it through the full legal appeals process, including if necessary to the Supreme Court, in order to generate a detailed debate on the extent to which human life is patentable.

Rejection by the court would also have

\section{Africa defends rights to indigenous knowledge}

[LONDON] All countries belonging to the Organization of African Unity (OAU) have agreed to consider refusing to recognize any patent on a drug made from natural products found in Africa unless it acknowledges the 'ownership' and contribution of the relevant community to the new product.

A model bill produced by an OAU committee states that ownership of new compounds should rest with indigenous local communities for "all times and in perpetuity".

It calls for states to develop laws guaranteeing such ownership. It also calls on collectors of natural products to share information with governments on "all discoveries" from research and development.
The draft bill was drawn up to harmonize African legislation on 'bioprospecting' by multinationals.

It was done partly to challenge the Trade Related Intellectual Property Rights Agreement (TRIPs) of the World Trade Organization (WTO), and partly to clamp down on the smuggling of medicinal plants.

The wording was finalized at a meeting of the OAU's scientific, technical and research commission in Addis Ababa, Ethiopia, last week. It will now be circulated among the OAU's 53 member states for comment before being presented as model legislation for African states.

The OAU believes that the TRIPs agreement violates the United Nations
Biodiversity Convention, which makes the "approval and involvement" of indigenous peoples a condition of developing a product based on a natural compound. According to the OAU, the TRIPs agreement makes no such provision.

Johnson Ekpere, the commission's executive secretary, says African countries want to bring TRIPs into line with the biodiversity convention.

But the draft will be controversial.

Some African states, such as Nigeria and Tanzania, are keen to attract overseas bioprospecting partners. They may be unwilling to pass legislation that could scare them away.

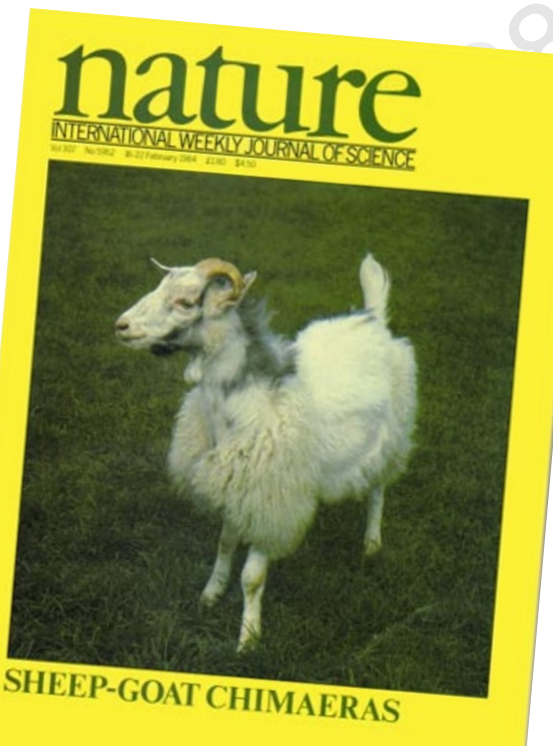

Mixing and

matching: experiments in the 1980s showed that chimaeras like this 'geep' are biologically viable.

important implications for any other patent application on techniques in the same field.

The issue has been highlighted by the fact that the patent applied for on techniques used to produce Dolly the sheep would embrace their use to clone humans (see Nature 387, 217; 1997). Under US law, humans cannot be patented, because this would contravene the Thirteenth Amendment to the constitution, outlawing human slavery.

But in 1980 the US Supreme Court handed down a landmark decision, based on an application from Ananda Chakrabarty covering a microorganism that had been modified to help clean up oil spills. It ruled that there was no bar to patents on living organisms, which can be considered as "compositions of matter" (see Nature 285, 528; 1980).

Although the same principle applies in Europe, illustrated for example by the decision to grant a patent on Harvard University's 'oncomouse' (see Nature 353, 589; 1991), a new directive on biotechnology patents explicitly rules out human/animal chimaeras.

But in the United States, even industry lawyers admit that there is no legal consensus on the boundary between the types of lifeform that can and cannot be patented. "Where the crossover point lies is certainly a grey area," says David Mickel, legal counsel to the Biotechnology Industry Organization in Washington DC.

The application describes three separate techniques for creating biologically viable chimaeras between species. The first, which involves mixing cells from the early embryos 
of two or more different animal species, was used to create the sheep-goat chimaera in Britain in the 1980s (see Nature307, 634-636 and 637-638; 1984).

In the second technique, which is widely used to introduce targeted mutations into mice, undifferentiated embryonic stem (ES) cells from the inner cell mass of preimplantation embryos are combined with normal preimplantation embryos.

The third technique combines so-called 'early passage' ES cells, those that have undergone only a few cell divisions, with embryos that have been altered to prevent them advancing beyond an early stage of development, but which will still allow the implanted ES cells to differentiate normally to form viable embryos.

In their patent application, Rifkin and Stewart say they can envisage ways in which one or more of these techniques could, in principle, be used to produce chimaeric embryos containing both human and animal cells that would have important applications for biomedical research. In particular, they identify:

- mouse/human embryos that could be used in developmental biology studies, particularly in investigating how cells from the two sources cooperate to form an embryo;

- baboon/human or chimpanzee/human embryos, of particular value to pharmaceutical and chemical companies for studying the teratogenic effects of new compounds; - chimpanzee/human chimaeras which could in principle - and provided that developmental incompatibilities between blastomeres or ES cells were overcome and the embryo brought to term — "provide ideal test systems for the cardiovascular effects of whole animal stress"; and

- chimpanzee/human and pig/human chimaeras, used for example as a source of hearts for transplantation to cardiac patients.

The breadth of the application, which is also intended to cover "the modifications and variations" of the techniques described, is already leading some patent lawyers to argue that, at the very least, its scope will be severely restricted by patent examiners before it is granted.

Its audacity leads others to dismiss it as little more than a joke. "This seems to be just a publicity stunt," says one British patent attorney (a related application is to be filed with the European Patent Office). "Chimaeras raise all kinds of emotive issues that go back to Greek mythology; I am rather bemused by the whole thing."

But Rifkin, who says there has been no serious public discussion of the patenting of life-forms in the United States since the Chakrabarty decision - which was itself approved by the Supreme Court by only a 5:4 majority - insists this is a serious attempt to stir up debate in political and legal circles.

"By having control of this patent, we will be able to provide countries around the world with the opportunity to debate the full implications," he says. "We think there should be a period of time for robust debate to establish the necessary guidelines."

Newman, too, is keen to have this discussion before the techniques become widely used. "No one has yet announced that they are going to do this type of thing," he says. "But it is clearly the type of thing that people would find useful, and I would far rather that

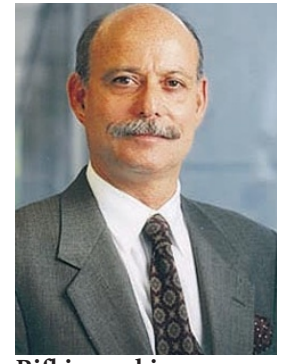

Rifkin: seeking a "genetic conservancy" we test the process and be in control than let it roll along with no public debate."

Jonathan Marks, who teaches biology and anthropology at the University of California, Berkeley, and includes discussion of the moral implications of crossing chimpanzees and humans in his lectures, says that "if this is what it takes to encourage geneticists to think more about humanistic issues, I am all for it", although he admits that he "would rather see it done more painlessly".

The process of dealing with initial comments from the US Patent Office, and if necessary contesting legal decisions through various stages, is likely to take years. During this time, as a patent applicant, Rifkin will have the legal standing to comment on similar applications made by others.

Given this prospect, many in the biotechnology industry are likely to see the application and the publicity campaign it is intended to stimulate as frivolous and irritating at best, and potentially disruptive at worst.

But even some geneticists who disagree with the anti-genetic engineering thrust of many of Rifkin's arguments accept the legitimacy of the issues he raises. "Setting aside the biological arguments, this is very much a mix of a legal and philosophical discussion," says David Porteous, of the UK Medical Research Council's Human Genetics Unit in Edinburgh. "It would certainly be a useful extension of the debate."

DavidDickson

\section{Neuroscientist accused of misconduct turns on his accusers}

[SAN DIEGO] A federal hearing whose outcome could have broad implications for US academic institutions began this week in Houston, Texas, about charges that a neuroscientist committed scientific misconduct.

The case has been watched closely by academic institutions, because it involves one of the most aggressive defences in the nascent history of formal misconduct inquiries: a legal attack on the accusers.

Kimon J. Angelides, who is 46, formerly of Baylor College of Medicine and now at the University of Durham in the United Kingdom, is appealing against a proposed five-year debarment by the National Institutes of Health (NIH) for falsifying and fabricating research data in grant proposals and five published articles (see Nature 383, 107; 1996).

His appeal is being heard by a threeperson panel during two-week proceedings, with lawyers for the government and Angelides taking testimony from and cross- examining about 25 witnesses, including Angelides himself.

The panel is to decide in June whether Angelides committed scientific misconduct - which both Baylor and the NIH's Office of Research Integrity (ORI) have previously ruled he did. Angelides was fired by Baylor in 1995 after the university concluded a lengthy investigation of the alleged misconduct between 1988 and 1992.

Angelides is suing Baylor and its officials in state court for wrongful termination, defamation and other offences. Angelides denies any misconduct, blaming any irregularities on other scientists who had worked in his laboratory studying the sodium channels of nerve cells. Angelides' civil lawsuit and misconduct allegations have been the subject of varied litigation.

Baylor unsuccessfully attempted to remove the lawsuit to federal court last year, pleading immunity from a lawsuit because it was following NIH guidelines on grantmonitoring. The US Attorney's Office in
Houston conducted an inquiry into Angelides, but closed it last summer without filing any criminal charges. Now the state trial on Angelides' lawsuit is set for October.

The outcome of the federal appeal hearing is likely to have a major impact. If the government's and Baylor's findings of misconduct are upheld, Angelides may have a difficult time winning his lawsuit. If the findings of misconduct are overturned, Baylor could find huge costs awarded against it by a jury hearing the lawsuit.

A government loss in the case and damage award against Baylor could embolden other accused scientists to follow a similar litigation course, thereby undermining government fraud-prevention efforts and sending a chilling message to academic institutions.

Angelides' co-authors for the five articles in question - most of whom are from Yale University - have sought to retract all five, but only two retractions have been published so far.

Rex Dalton 